\title{
Pengaruh Penggunaan Limbah Cair Pabrik Kelapa Sawit Terhadap Perubahan Sifat Kimia Ultisol dan Pertumbuhan Bibit Kelapa Sawit (Elaeis guineensis Jacq)
}

\author{
(Effect of Palm Oil Mill Liquid Waste Use on Changes in Chemical Properties of Ultisols and Growth \\ of Oil Palm Seeds (Elaeis guineensis Jacq)
}

\author{
Hasbi $^{1}$, Zainabun ${ }^{1}$, Yadi Jufri ${ }^{1 *}$ \\ ${ }^{1}$ Program StudiIlmu Tanah, FakultasPertanian, UniversitasSyiah Kuala \\ *Corresponding author:emailpembimbingutama@unsyiah.ac.id
}

\begin{abstract}
Abstrak. Kelapa sawit (Elaeis guineensis Jacq.) merupakan salah satu tanaman penghasil minyak nabati yang sangat penting. Produksi minyak kelapa sawit perhektar merupakan produksi paling tinggi dibandingkan denganseluruh tanaman penghasil minyak nabati lainnya. Perindustrian di bidang kelapa sawit banyak mengeluarkan serat dan residu hasil pengolahan seperti limbah cair dan limbah padat. Limbah cair yang dihasilkan berupa Palm oil mill Effluent (POME) air buangan kondensat (8-12\%) dan air hasil pengolahan (13-23\%). Dalam1 ton hasil kelapa sawit dapa tmengeluarkan limbah yang tidak bisa di pakai atau beracun mencapai $600-700 \mathrm{~kg}$ limbah cair. Meningkatnya kualitas tanah dan sifat-sifat Ultisol seperti sifat fisik, biologi dan kimia tanah memerlukan suatu pengelolaan tanah dengan memberikan bahan organik seperti limbah cair kelapa sawit (sludge) yang tepat dan efisien sehingga dapat meningkatkan produktifitas tanah, karena bahan organik yang terkandung dalam limbah cair pabrik kelapa sawit baik untuk sifat kimia tanah dan dapat dipergunakan sebagai pengganti pupuk kimia untuk pupuk bibit kelapa sawit. Dalam penelitian ini menggunakan pendekatan penelitian kuantitatif dan didapatkan bahwa Pemberian limbah cair kelapa sawit dapat mempengaruhi sifat kimia tanah Ultisol dengan adanya peningkatan beberapa parameter kimia tanah baik dari pH dari 4,94 menjadi 5,26 setelah pemberian limbah cair kelapa sawit dengan pemberian $2400 \mathrm{ml}$ per polibag $\left(\mathrm{L}_{4}\right)$ dan Adapun parameter lainnya.
\end{abstract}

\section{Kata kunci: KelapaSawit, Tanah Ultisol, Sifat Kimia}

Abstract. Oil palm (Elaeis guineensis Jacq.) is one of the most important vegetable oil-producing plants. Palm oil production per hectare is the highest production compared to all other vegetable oil producing plants. The industry in the palm oil sector emits a lot of fiber and residues from processing such as liquid waste and solid waste. The liquid waste produced is in the form of Palm oil mill Effluent (POME), condensate waste water (8-12\%) and treated water (13-23\%). In 1 ton of palm oil products can produce waste that cannot be used or toxic up to 600$700 \mathrm{~kg}$ of liquid waste. Improving soil quality and Ultisol properties such as soil physical, biological and chemical properties requires a soil management by providing appropriate and efficient organic matter such as palm oil waste (sludge) so as to increase soil productivity, because of the organic matter contained in liquid waste. Palm oil mills are good for the chemical properties of the soil and can be used as a substitute for chemical fertilizers for fertilizers for oil palm seeds. In this study using a quantitative research approach and it was found that the application of palm oil effluent can affect the chemical properties of Ultisol soil with an increase in several soil chemical parameters, both from $\mathrm{pH}$ from 4.94 to 5.26 after administration of palm oil effluent by giving $2400 \mathrm{ml}$ per polybag (L4) and other parameters.

Keywords: Oil Palm, Ultisol Soil, Chemical Properties

\section{PENDAHULUAN}

Kelapa sawit (Elaeis guineensis Jacq.) merupakan salah satu tanaman penghasil minyak nabati yang sangat penting. Produksi minyak kelapa sawit perhektar merupakan produksi paling tinggi dibandingkan dengan seluruh tanaman penghasil minyak nabati lainnya (Pahan, 2008). Kelapa sawit menyumbang minyak nabati terbesar di dunia yaitu 2.000-3.000 kg ha-1 (Irvan et al, 2009). Peningkatan produksi nasional CPO (Crude Palm Oil) terjadi seiring dengan peningkatan areal lahan untuk budidaya kelapa sawit. Luas areal perkebunan kelapa sawit tahun 2018 mencapai 14,5juta ha. Produksi CPO kelapa sawit pada tahun 2018 mencapai 37,8 juta ton dengan produktivitas CPO mencapai $3.571 \mathrm{~kg} \mathrm{ha}^{-1}$ (Direktorat Jenderal Perkebunan 
Kementerian Pertanian, 2018). Devisa dari sektor perkebunan mencapai US\$ 20 miliar pada tahun 2010 yang sebagian besar berasal dari kelapa sawit yaitu US\$ 15.5 miliar (Ditjenbun, 2018). Perindustrian di bidang kelapa sawit banyak mengeluarkan serat dan residu hasil pengolahan seperti limbah cair dan limbah padat. Limbah cair yang dihasilkan berupa Palm oil mill Effluent (POME) air buangan kondensat (8-12\%) dan air hasil pengolahan (13-23\%). Dalam1 ton hasil kelapa sawit dapat mengeluarkan limbah yang tidak bisa di pakai atau beracun mencapai 600-700 kg limbah cair (Djajadiningrat dan Femiola, 2004).

Menurut Siregar dan Liwang (2001) limbah cair pabrik kelapa sawit (LCPKS) mengandung Biological Oxiygen Demand (BOD) yang masih segar mengandung 20.000$60.000 \mathrm{mg} / \mathrm{L}$ sebagai bahan pencemar apabila dibuang keperairan bebas karena dapat berpotensi merusak lingkungan. Limbah cair ini bisa di jadikan sebagai sumber bahan organik karena mengandung sumber hara dan air yang berperan dalam memperbaiki beberapa sifat fisik tanah di antaranya kelembaban tanah, meningkatkan hasil tanaman. Mengurangi biaya dan waktu pengolahan. Menurut Febriana (2009), gejala defisiensi unsur hara adalah tanda-tanda yang diperlihatkan oleh tanaman sebagai akibat kekurangan salah satu atau lebih unsur hara. Defisiensi unsur hara antara lain disebabkan oleh pemupukan yang dilakukan sebelumnya tidak sesuai dengan kebutuhan tanaman

Meningkatnya kualitas tanah dan sifat-sifat Ultisol seperti sifat fisik, biologi dan kimia tanah memerlukan suatu pengelolaan tanah dengan memberikan bahan organic seperti limbah cair kelapa sawit (sludge) yang tepat dan efisien sehingga dapat meningkatkan produktifitas tanah, karena bahan organik yang terkandung dalam limbah cair pabrik kelapa sawit baik untuk sifat kimia tanah dan dapat dipergunakan sebagai pengganti pupuk kimia untuk pupuk bibit kelapa sawit.

\section{METODE PENELITIAN}

Penelitian ini dilakukan di Pabrik Kelapa Sawit PT Bangun Sempurna Lestari tepatnya di Desa Sikalondang Kecamatan Simpang Kiri Kota Subulussalam. Penelitian ini berlangsung selama tiga bulan dari bulan Oktober 2019 - Desember 2019. Analisis sampel tanah dan tanaman dilakukan di Laboratorium Penelitian Tanah dan Tanaman Fakultas Pertanian Universitas Syiah Kuala.

\section{Pengambilan Sampel Tanah}

Tanah yang digunakan adalah bahan tanah Ultisol yang diambil di Desa Sikalondang Kecamatan Simpang Kiri Kota Subulussalam. Kemudian ditumbuk dan dihaluskan menggunakan ayakan, dan dimasukkan kedalam polybag isi $10 \mathrm{~kg}$, diinkubasi selama 3 hari setelah itu diberi limbah cair sesuai perlakuan dan kembali di inkubasi selama 3 hari.

Selanjutnya tanaman akan mengalami berbagai tahapan dari pemilihan bibit yang memiliki umur 3-4 bulan, Pemupukan, dan juga perawatan dilakukan berupa penyiangan gulma yang dilakukan setiap 3 minggu sekali, Penyiraman dilakukan pada pagi dan sore hari. Pengendalian hama dan penyakit dilakukan jikalau ada hama yang menyerangnya

\section{Analisa Sifat Kimia Tanah Awal}

Analisis Kimia Tanah Ultisol

Adapun parameter yang analisis tanah awal diantaranya $\mathrm{pH}, \mathrm{N}-$ Total, $\mathrm{P}$ tersedia, K-dd, dan KTK. Sifat kimia tanah Ultisol yang mengganggu pertumbuhan tanaman adalah $\mathrm{pH}$ yang rendah (masam) yaitu $<5,0$ dengan kejenuhan Al tinggi yaitu $>42 \%$ kandungan bahan organic rendah yaitu $<1,15 \%$, kanndungan hara rendah yaitu $\mathrm{N}$ berkisar $0,14 \%$, P sebesar $5,80 \mathrm{ppm}$, 
kejenuhan basa rendah yaitu 29\% dan KTK juga rendah yaitu sebesar 12,6 me/100g. Hal tersebut dijabarkan seperti yang tertera pada Tabel 1.

Tabel 1. Analisis Kimia Tanah Ultisol

\begin{tabular}{ccc}
\hline Kimia Tanah & Metode & Alat \\
\hline $\mathrm{pH}$ & Elektrometrik & Elektormtrik \\
N-Total & Kjeldhal atau Destilasi & Spectrophotometer \\
P-Tersedia & Bray II & Spectrophotometer \\
K-dd & $\mathrm{HCl} \mathrm{25 \%}$ & Spectrophotometer \\
KTK & Ekstrak NH ${ }_{4} \mathrm{OA}_{\mathrm{C}} \mathrm{pH} 7.0$ & Destilasi Unit \\
\hline
\end{tabular}

\section{Analisis Awal Limbah Cair Kelapa Sawit}

Dalam analisis ini juga melibatkan beberapa komponen yang telah dijabarkan dalam analisis kimia tanah, yang ditujukan dengan Tabel 2.

Tabel 2. Analisis Awal Limbah Cair Kelapa Sawit

\begin{tabular}{cc}
\hline Parameter & Kandungan \\
\hline $\mathrm{N}$ & $500-900 \mathrm{mg} / \mathrm{l}$ \\
$\mathrm{P}$ & $90-140 \mathrm{mg} / \mathrm{l}$ \\
$\mathrm{K}$ & $260-400 \mathrm{mg} / \mathrm{l}$ \\
BOD & $96,6 \mathrm{mg} / \mathrm{l}$ \\
$\mathrm{COD}$ & $211,50 \mathrm{mg} / \mathrm{l}$ \\
\hline
\end{tabular}

\section{Analisis Data Akhir}

Adapun parameter sifat kimia tanah yang di analisis akhir diantaranya $\mathrm{pH}, \mathrm{N}$-Total, $\mathrm{P}$ Tersedia, K-dd dan KTK. Analisis kimia dilakukan sesuai metode seperti tertera pada Tabel 3.

Tabel 3. Analisis Akhir Kimia Tanah

\begin{tabular}{ccc}
\hline Kimia Tanah & Metode & Alat \\
\hline $\mathrm{pH}$ & Elektrometrik & Elektormtrik \\
N-Total & Kjeldhal atau Destilasi & Spectrophotometer \\
P-Tersedia & Bray II & Spectrophotometer \\
K-dd & HCL 25\% & Spectrophotometer \\
KTK & Ekstrak NH NACpH7.0 $_{4}$ Destilasi Unit \\
\hline
\end{tabular}

\section{HASIL DAN PEMBAHASAN}

\section{Sifat Kimia Ultisol}

Hasil analisis tanah Ultisol yang dilakukan di Laboratorium Penelitian Tanah dan Tanaman Fakultas Pertanian Universitas Syiah Kuala.

Berdasarkan table diatas menunjukkan bahwa sifat kimia pada tanah awal memiliki $\mathrm{pH}$ yang agak masam, N-Total dan KTK tergolong rendah, dan K tergolong sangat rendah. Berdasarkan analisis diatas yang telah dilakukan, Ultisol ini memiliki tingkat kesuburan yang rendah sehingga tanah ini belum dimanfaatkan dengan maksimal (Fitriani et al., 2014).

Dari data Tabel 4 menunjukan bahwa terjadi peningkatan $\mathrm{pH}$ tanah awal dari 4,94 menjadi 5,08 sampai 5,26 setelah pemberian limbah cair kelapa sawit. Dibandingkan dengan $\mathrm{pH}$ tanah awal peningkatan terjadi setelah pemberian limbah cair kelapa sawit dengan $\mathrm{pH}$ tertinggi pada perlakuan $\mathrm{L}_{4}$ dengan takaran limbah cair kelapa sawit sebanyak $2400 \mathrm{ml}$. Hal ini di sebabkan dengan pemberian limbah cair kelapa sawit terjadi perubahan $\mathrm{pH}$ tanah Ultisol di karenakan limbah cair kelapa sawit mengandung bahan organik yang tinggi. Walaupun peningkatannya tidak secara signifikan tapi limbah cair kelapa sawit mampu meningkatkan $\mathrm{pH}$ 
tanah. Unsur hara yang mudah di serap tanaman di tentukan oleh keadaan tanahnya itu sendiri dalam hal ini tanah netral sangat mudah untuk di serap bagi tanaman karena mudah larut dalam air. (Hardjowigeno, 2007).

Tabel 4 Hasil Pengukuran Sifat Kimia Tanah Sesudah Diberi Perlakuan

\begin{tabular}{|c|c|c|c|c|c|c|c|}
\hline \multirow[b]{2}{*}{ No } & \multirow[b]{2}{*}{$\begin{array}{l}\text { Kode } \\
\text { Perlakuan }\end{array}$} & \multirow[b]{2}{*}{ Data Awal } & \multicolumn{5}{|c|}{ Rata-rata setelah perlakuan } \\
\hline & & & $\mathrm{pH}$ & $\begin{array}{c}\mathrm{N} \\
(\%)\end{array}$ & $\begin{array}{c}\mathrm{P} \\
(\mathrm{ppm})\end{array}$ & $\begin{array}{c}\mathrm{K} \\
(\mathrm{cmol} / \mathrm{kg})\end{array}$ & $\begin{array}{c}\mathrm{KTK} \\
(\mathrm{cmol} / \mathrm{kg})\end{array}$ \\
\hline 1 & L0 & $4,94(\mathrm{pH})$ & 5,12 & 0,03 & $1,63 \mathrm{a}$ & $0,37 \mathrm{a}$ & $10,3 \mathrm{c}$ \\
\hline 2 & L1 & $0,03(\mathrm{~N})$ & 5,09 & 0,04 & $1,45 \mathrm{a}$ & $0,45 \mathrm{~b}$ & $10,1 \mathrm{bc}$ \\
\hline 3 & L2 & $1,10(\mathrm{P})$ & 5,18 & 0,04 & $1,59 \mathrm{a}$ & $0,49 \mathrm{bc}$ & 9,9 bc \\
\hline 4 & L3 & $0,06(\mathrm{~K})$ & 5,22 & 0,04 & $2,26 \mathrm{c}$ & $0,46 \mathrm{~b}$ & $9,3 \mathrm{a}$ \\
\hline 5 & L4 & 8,0 (KTK) & 5,27 & 0,05 & $2,07 \mathrm{~b}$ & $0,52 \mathrm{c}$ & $9,8 \mathrm{~b}$ \\
\hline 6 & L5 & & 5,20 & 0,04 & $3,00 \mathrm{~d}$ & 0,48 bc & $9,1 \mathrm{a}$ \\
\hline & $\mathrm{BNJ}_{0,05}$ & & & & 0,89 & 0,050 & 0,40 \\
\hline
\end{tabular}

N-Total pada tanah awal 0,03 yang dimana peningkatan setelah perlakuan berkisar antara 0,03 sampai dengan 0,05. Dibandingkan dengan tanah awal, pemberian limbah cair kelapa sawit mengalami perubahan nilai $\mathrm{N}$ total tertinggi dijumpai pada perlakuan $\mathrm{L}_{4}$ dengan takaran limbah cair kelapa sawit sebanyak $2400 \mathrm{ml}$ dengan $\mathrm{N}$ total rata-rata 0,05 . Hal ini disebabkan karena dengan pemberian limbah cair kelapa sawit akan meningkatkan Nilai $\mathrm{N}$ total kerena limbah cair kelapa sawit banyak mengandung bahan organik. Walaupun secara statistic tidak berbeda nyata namun memberikan pengaruh yang baik bagi tanaman dan tanah. Rendahnya N-Total diduga karena sebagian telah diserap oleh tanaman, dan mengalami penguapan serta pencucian. Proses hilangnya $\mathrm{N}$ yang ada dalam tanah dapat disebabkan karena diserap oleh tanaman (Hardjowigeno, 2003).

P- tersedia pada tanah awal adalah 1,10 ppm mengalami peningkatan dari 1,79a sampai 9,28d. Di bandingkan dengan P-Tersedia tanah awal setelah pemberian limbah cair kelapa sawit peningkatan terjadi yang dimana diantara semua perlakuan yang paling tinggi iyalah pada perlakuan L5 dengan rata-rata 9,25. Hal ini di sebabkan dengan meningkatnya kandungan PTersedia dari pengaruh limbah cair, karena mengandung bahan organik. Pelapukan batuan dalam tanah dominan oleh kandungan P sedangkan limbah berasal dari P- organic (Istono, 2006)

K-dd tanah awal 0,06 terjadi peningkatan dari 0,37a sampai 0,52c setelah pemberian limbah cair kelapa sawit. Di bandingkan dengan semua perlakuan terdapat yang tertinggi pada perlakuan L4 dengan rata-rata 0,52c dengan takaran limbah cair sebanyak $2400 \mathrm{ml}$ sementara yang terendah di perlakuan L1 dengan rata-rata $0,37 \mathrm{a}$. Hal ini disebabkan meningkatnya K-dd tanah akibat pengaruh limbah cair dengan perlakuan L4 yang bagus untuk tanaman. Tanaman akan menyerap kalium dalam bentuk ion $\mathrm{K}^{+}$setelah unsur Nitrogen dan Fosfor. Ketersedian $\mathrm{K}$ di pertukarkan diserap oleh tanaman, Dengan adanya fiksasi dapat menambah kaliumnya (Sutedjo, 2008). Penyusun bagian tanaman dari unsur K rata-rata menyusun 1,0\% tanaman. Kandungan N, S, dan P sedikit berfungsi sebagai penyusun komponen tanaman selulosa, tetapi berfungsi sebagai katalisator seperti fotosintesis (Hanafiah, 2005).

KTK pada tanah awal 8,0 terjadi peningkatan antara 9,1 sampai 10,3. Setelah pemberian limbah cair kelapa sawit di setiap perlakuan mengalami peningkatan yang dimana dapat kita lihat yang tertinggi iyalah pada perlakuan L0 dengan rata-rata 10,3c yang terendah pada perlakuan L5 dengan takaran limbah cair kelapa sawit $3000 \mathrm{ml}$ dengan rata-rata 9,1a. Hal ini di sebabkan dengan pemberian limbah cair kelapa sawit dapat meningkatkan KTK, namun yang terendah pada perlakuan L5 dengan takaran yang paling tinggi dengan demikian di duga karena 
di akibatkan oleh di serapnya oleh tanaman bibit kelapa sawit untuk pertumbuhan dan perkembangan.

\section{Pertumbuhan Tanaman Kelapa Sawit \\ Tinggi Tanaman}

Berdasarkan hasil pengukuran pada L0 (tanpa limbah) dengan L1, L2, L3, L4, L5 (limbah cair) berpengaruh nyata terhadap tinggi tanaman baik 15 HST sampai dengan 75 HST seperti pada Tabel 5.

Tabel 5. Rata-Rata Pertumbuhan Tanaman Kelapa Sawit

\begin{tabular}{|c|c|c|c|c|c|c|c|}
\hline \multirow[b]{2}{*}{ No } & \multirow[b]{2}{*}{$\begin{array}{l}\text { Kode } \\
\text { Perlakuan }\end{array}$} & \multicolumn{6}{|c|}{ Rata-rata Laju Tumbuh } \\
\hline & & $0 \mathrm{HST}$ & $15 \mathrm{HST}$ & $30 \mathrm{HST}$ & $45 \mathrm{HST}$ & $60 \mathrm{HST}$ & 75 HST \\
\hline 1 & $\mathrm{~L}_{0}$ & 8,75 & $9,38 \mathrm{a}$ & $10,50 \mathrm{a}$ & $12,25 \mathrm{a}$ & $12,88 \mathrm{a}$ & $13,25 \mathrm{a}$ \\
\hline 2 & $\mathrm{~L}_{1}$ & 11,00 & $12,13 \mathrm{~cd}$ & $12,50 \mathrm{a}$ & $14,00 \mathrm{a}$ & $14,38 \mathrm{a}$ & $15,63 \mathrm{ab}$ \\
\hline 3 & $\mathrm{~L}_{2}$ & 9,75 & $11,63 \mathrm{bc}$ & $12,63 \mathrm{a}$ & $14,00 \mathrm{a}$ & $14,88 \mathrm{a}$ & $15,50 \mathrm{ab}$ \\
\hline 4 & $\mathrm{~L}_{3}$ & 10,25 & $11,00 \mathrm{~b}$ & $12,38 \mathrm{a}$ & 13,63 a & 15,13 a & $17,63 \mathrm{~b}$ \\
\hline 5 & $\mathrm{~L}_{4}$ & 8,50 & 9,88 a & 10,88 a & 13,13 a & 14,88 a & $16,75 \mathrm{~b}$ \\
\hline \multirow[t]{2}{*}{6} & $\mathrm{~L}_{5}$ & 11,50 & $12,75 \mathrm{~d}$ & $16,25 \mathrm{~b}$ & $19,25 \mathrm{~b}$ & $22,00 \mathrm{~b}$ & $22,75 \mathrm{c}$ \\
\hline & $\mathrm{BNJ}_{0,05}$ & & 0,86 & 2,50 & 2,86 & 3,41 & 3,42 \\
\hline
\end{tabular}

Berdasarkan tabel 5 pada pertumbuhan 15 HST menunjukan bahwa pemberian limbah cair kelapa sawit berbeda nyata dengan tanpa pemberian limbah cair kelapa sawit. Rata-rata tinggi tanaman tertinggi di peroleh pada pemberian limbah cair kelapa sawit dengan takaran $3000 \mathrm{ml}$ dengan rata-rata $12,75 \mathrm{c} \mathrm{cm}$ dan terendah pada pemberian limbah cair kelapa sawit dengan takaran $1800 \mathrm{ml}$ dengan rata-rata $11 \mathrm{~cm}$. Hal ini di sebabkan dengan pemberian limbah cair kelapa sawit dapat meningkatkan pertumbuhan dan perkembangan bibit kelapa sawit. Oleh karena itu, pemberian limbah cair yang sesuai dengan takaran yang tepat akan meningkatkan pertumbuhan dan perkembangan serta unsur hara pada tanaman kelapa sawit. Khairul dkk. (2016) menjelaskan adanya peningkatan laju fotosintesis yang diikuti adanya pertambahan jumlah daun, sehingga jumlah daun yang sedikit menghambat fotosintesis (Prawiranata 1995).

Pertumbuhan 30 HST bahwa nilai rata-rata tertinggi di jumpai pada perlakuan L5 yaitu dengan nilai 16,25b berbeda dengan perlakuan L0 dengan nilai 10,5 dengan tanpa pemberian limbah cair. Rata-rata tinggi tanaman di peroleh dari perlakuan L5 dengan takaran limbah 3000 $\mathrm{ml}$ limbah cair kelapa sawit. Hal ini disebabkan dengan penggunaan pupuk mampu meningkatkan pertumbuhan bibit kelapa sawit karena kandungan bahan organik pada limbah cair kelapa sawit di serap oleh tanaman. Pentingnya bahan organic sebagai penyangga sifat fisik dan kimia tanah, yang dimana berperan bukan untuk dapat meningkatkan agregat dan memperbaiki struktur (Sutedjo, 2002).

Pada 45 HST menunjukan bahwa rata-rata pertumbuhan tinggi tanaman akibat pemberian limbah cair kelapa sawit berkisar antara 12,25a cm sampai 19,5b cm. Perbedaan rata-rata tinggi tanaman antar seluruh perlakuan berbeda nyata, pada perlakuan L0 kontrol tanpa perlakuan sangat berbeda nyata terhadap perlakuan L5 limbah cair kelapa sawit dengan takaran $3000 \mathrm{ml}$. Hal ini disebabkan dengan bertambah banyak pemberian limbah cair maka pertumbuhan tanaman semakin meningkat. Perkembangan Tanaman sangat berpengaruh pada unsur hara organic karena pada saat perkembangan vegetative tanaman membutuhkan unsur hara dalam jumlah yang banyak untuk perkembangannya (Djazuli dan Trisilawati, 2004). 
Pada 60 HST menunjukan bahwa rata-rata tinggi tanaman akibat pemberian limbah cair kelapa sawit berkisar antara $12,87 \mathrm{a} \mathrm{cm}$ sampai dengan $22 \mathrm{~b} \mathrm{~cm}$. Hal ini disebabkan perbedaan takaran limbah cair kelapa sawit tidak sama yang di berikan. Pada perlakuan L5 limbah cair yang di berikan sebanyak $3000 \mathrm{ml}$, sementara pada L0 tanpa di beri limbah. Dengan pemberian limbah cair kelapa sawit dengan takaran $3000 \mathrm{ml}$ bibit kelapa sawit pertumbuhan dan perkembangannya sangat bagus bias disebut dengan takaran demikian sangat cocok untuk pembibitan kelapa sawit. Penambahan pupuk organic dapat berpengaruh nyata, akan tetapi penambahan yang sedikit tidak pengaruh dan jika terlalu berlebihan dapat meracuni tanaman, sehingga penambahan yang baik harus mengetahui batasan kebutuhan pupuk organic tersebut. (Lingga dan Marsono, 2005)

Pada 75 HST menunjukan bahwa rata-rata tinggi tanaman akibat pemberian limbah cair kelapa sawit berkisar antara 13,25a sampai dengan 22,75c. Hal ini disebabkan berbeda perlakuan dan beda pemberian takaran pada tanah, pada perlakuan L0 kontrol rata-rata tinggi tanamannya 13,25a cm termasuk nilai rata-rata terendah. Sementara perlakuan L5 dengan takaran $3000 \mathrm{ml}$ menghasilkan tanaman yang tertinggi. Yulipriyanto (2010) menyatakan bahwa pengaruh positif lain dengan pemberian pupuk organik yaitu dapat memperbaiki struktur tanah, meningkatkan porositas, aerasi dan komposisi mikroorganisme tanah, meningkatkan daya ikat tanah terhadap air dengan meningkatnya kemampuan tanah dalam mengikat air maka akar-akar tanaman akan mudah menyerap zat-zat makanan bagi pertumbuhan tanaman.

\section{Berat Basah dan Kering Tanaman}

Hasil analisis laboratorium menunjukan pada perlakuan tanpa limbah cair kelapa sawit berbeda nyata dengan perlakuan yang diberikan limbah cair kelapa sawit terhadap berat basah dan berat kering pada tanaman kelapa sawit. Rata-rata berat basah dan berat kering dapat dilihat pada tabel 6 .

Tabel 6. Rata-Rata Berat Basah dan Kering Tanaman

\begin{tabular}{lccc}
\hline & & \multicolumn{2}{c}{ Rata-rata beratbasah dan kering } \\
\cline { 3 - 4 } No & Kode perlakuan & Berat Basah & Berat Kering \\
\hline 1 & $\mathrm{~L}_{0}$ & $2,71 \mathrm{a}$ & $0,89 \mathrm{a}$ \\
2 & $\mathrm{~L}_{1}$ & $4,95 \mathrm{bc}$ & $1,55 \mathrm{ab}$ \\
3 & $\mathrm{~L}_{2}$ & $3,67 \mathrm{ab}$ & $1,22 \mathrm{a}$ \\
4 & $\mathrm{~L}_{3}$ & $4,56 \mathrm{abc}$ & $1,49 \mathrm{ab}$ \\
5 & $\mathrm{~L}_{4}$ & $6,08 \mathrm{~cd}$ & $2,48 \mathrm{bc}$ \\
6 & $\mathrm{~L}_{5}$ & $7,71 \mathrm{~d}$ & $2,8 \mathrm{c}$ \\
\hline & $\mathrm{BNJ}_{0,05}$ & 2,14 & 1,02 \\
\hline
\end{tabular}

Berat basah menunjukan bahwa nilai rata-rata berat basah berkisar antara 2,71a $\mathrm{g}$ sampai 7,71c g, Nilai terberat dijumpai pada perlakuan $L_{5}$ dengan pemberian limbah cair kelapa sawit dengan takaran $3000 \mathrm{ml}$, berbeda nyata dengan perlakuan tanpa pemberian limbah cair kelapa sawit dengan perlakuan $\mathrm{L}_{0}$ namun tidak berbeda nyata dengan perlakuan pemberian limbah cair kelapa sawit sebanyak $2400 \mathrm{ml}$ (Perlakuan L4). Dalam hal ini diduga pemberian limbah cair kelapa sawit dapat terpenuhi dan ketersedian batang pada bibit kelapa sawit sehingga dapat menambah berat basah pada tanaman dan daya serap air pada tanaman kelapa sawit intens. Shinde dan Laware (2010), menyatakan bahwa kekurangan air pada masa pertumbuhan dapat berpengaruh terhadap penurunan berat segar tanaman. Hal ini di karenakan air sangat berpengaruh terhadap pertumbuhan dan perkembangan tanaman. 
Berat kering pada tanaman menunjukkan bahwa nilai rata-rata berat kering bibit kelapa sawit berkisar antara $0,89 \mathrm{~g}$ sampai $2,8 \mathrm{~g}$. Nilai terberat dijumpai pada perlakuan $\mathrm{L}_{5}$ dengan takaran $3000 \mathrm{ml}$ pemberian limbah cair kelapa sawit dengan nilai rata-rata 2,8 g sementara yang terendah 0,89 pada perlakuan $\mathrm{L}_{0}$ dengan tanpa pemberian limbah cair kelapa sawit. Dengan pemberian limbah cair kelapa sawit nilai rata-rata menjadi berbeda nyata dengan tanpa perlakuan limbah cair kelapa sawit. Air merupakan factor penting bagi tanaman. Disamping sebagai bahan baku proses fotosintesis, air bertindak pula sebagai pelarut, reagensia pada bermacam-macam reaksi dan sebagai pemelihara turgor tanaman (Pangaribuan, 2001). Semakin besar penimbunan berat kering pada tanaman, menggambarkan bahwa tanaman tersebut memiliki laju pertumbuhan yang tinggi pula. Sebab berat kering tanaman merupakan hasil dari asimilasi fotosintat yang ditranslokasikan dari akar keseluruh bagian tanaman. Berat kering tanaman dari hasil protoplasma dapat menambah ukuran dan jumlah sel (Heddy, 2001).

\section{KESIMPULAN DAN SARAN}

1. Pemberian limbah cair kelapa sawit dapat mempengaruhi sifat kimia tanah Ultisol dengan adanya peningkatan beberapa parameter kimia tanah yaitu:

a. pH tanah, terjadi peningkatan $\mathrm{pH}$ dari 4,94 menjadi 5,26 setelah pemberian limbah cair kelapa sawit dengan pemberian $2400 \mathrm{ml}$ per polibag $\left(\mathrm{L}_{4}\right)$

b. N-total, terjadi peningkatan kandungan $\mathrm{N}$-total dari 0,03\% menjadi 0,05\%. Setelah pemberian limbah cair kelapa sawit dengan pemberian $2400 \mathrm{ml} /$ polibag $\left(\mathrm{L}_{4}\right)$

c. P-tersedia, terjadi peningkatan $\mathrm{P}$ tersedia dari $1,10 \mathrm{ppm}$ menjadi $9,28 \mathrm{ppm}$ setelah pemberian limbah cair kelapa sawit sebanyak $1200 \mathrm{ml} /$ polibag $\left(\mathrm{L}_{2}\right)$

d. K-dd, terjadi peningkatan nilai K-dd dari $0,06 \mathrm{cmol} / \mathrm{kg}$ menjadi $0,52 \mathrm{cmol} / \mathrm{kg}$ setelah pemberian limbah cair kelapa sawit sebanyak $2400 \mathrm{ml} /$ polibag $0,52\left(\mathrm{~L}_{4}\right)$

e. Nilai KTK, terjadi peningkatan nilai KTK dari $8,0 \mathrm{cmol} / \mathrm{kg}$ menjadi $10,3 \mathrm{cmol} / \mathrm{kg}$ pada perlakuan $\mathrm{L}_{0}$ tanpa pemberian limbah cair kelapa sawit.

2. Pemberian limbah cair kelapa sawit dapat meningkatkan pertumbuhan bibit kelapa pada umur 15 HST, 30 HST, 45 HST, 60 HST dan 75 HST, berat berangkasan basah dan berangkasan kering dengan perlakuan terbaik terdapat pada pemberian limbah cair kelapa sawit sebanyak $3000 \mathrm{ml} /$ polibag (Perlakuan $\mathrm{L}_{5}$ )

3. Dari penelitian ini menunjukan dengan pemberian limbah cair kelapa sawit dapat meningkatkan sifat kimia tanah dan pertumbuhan bibit kelapa sawit. Maka di perlukan penelitian lanjutan dengan tanaman yang berbeda.

\section{DAFTAR PUSTAKA}

Anief, Ma., 2000, Limbah cair kelapa sawit, Gadjah Mada University Press, Yogyakarta

Direktorat Pengolahan Hasil Pertanian, Ditjen Pengolahan dan Pemasaran Hasil Pertanian, Departemen Pertanian. 2006. Program Bio Energi Pedesaan: Biogas Skala RumahTangga. Jakarta.

Direktorat Jenderal Perkebunan Kementerian Pertanian (Kemtan), 2018. Badan Pusat Statistik. Jakarta.

Direktorat Jenderal Perkebunan. 1995. Petunjuk Teknis Budidaya Teh. Direktorat Jenderal Perkebunan, Departemen Pertanian. Jakarta. 65 hal.

Djajadiningrat dan Famiola. 2004. Kawasan Industri Berawawasan Lingkungan. Bandung Penerbit Rekayasa Sains 
Dradjat, B. 2008. Prospek Kebun Sawit Masih Cerah. Lembaga Riset Perkebunan Indonesia. Jakarta.

Febriana, R. 2009. Pengelolan pemupukan tanaman sawit di perkebunan PT. Sari Loka I (PT Astra Agro Lestari, Tbk), kabupaten Merangin, Provinsi Jambi. [Skripsi]. Fakultas Pertanian, Institut Pertanian Bogor. $110 \mathrm{hlm}$.

Harahap, O, A. 2010. Pemanfaatan Kompos Tandan Kosong Kelapa Sawit Dan KonsentratLimbah Cair Pabrik Kelapa Sawit Untuk Memperbaiki Sifat Kimia Media Tanam Sub Soil Ultisol Dan Pertumbuhan Bibit Kelapa Sawit (Elaeis guineensis Jacq.). Universitas Sumatera Utara, Medan.

Hartawan. 2006. Pembibitan Kelapa Sawit. PT Rineka Cipta, Jakarta

Irvan, H., H. Agusta, dan S. Yahya. 2009. Pengelolaan Limbah Kelapa Sawit (Elaeis guiennensis Jacq) di Sungai Pinang Estate, PT Bina Sains Cemerlang, Minamas Plantation, Sime Darby Group Kabupaten Musi Rawas, Provinsi Sumatera Selatan. Makalah seminar. Departemen Agronomi dan Hortikultura, Fakultas Pertanian. IPB. Bogor.

Khaswarina, S. 2011. Jurnal Natur Indonesia Keragaman Bibit Kelapa Sawit Terhadap Pemberian Berbagai Kombinasi Pupuk di Pembibitan Utama. Fakultas Pertanian Universitas Sumatera Utara.

Kementrian Perdagangan Republik Indonesia, 2013. Market Brief Kelapa Sawit dan Olahannya. ITPC Hamburg. Hamburg. Diakses dari http://djpen.kemendag.go.id pada tanggal 19 Mei 2014.

Leszczynska, D. dan Malina, J.K. 2011. Effect of organic matter from various sources on yield and quality of plant on soils contaminated with heavy metals. J. Ecol. Chem. Engineering 18:501-507.

Loebis, B. dan Tobing, P.L. 1989. Hasil Sigi Pengendalian Air Limbah Pabrik Minyak Kelapa Sawit. Seminar Nasional Pengendalian Limbah Pabrik Minyak Kelapa Sawit dan Karet. Medan.

Mangoensoekarjo, S. 2007. Manajemen Tanah dan Pemupukan Budidaya Perkebunan. Gadjah Mada Universuty Press. Yogyakarta.

Maas, A. 1997. Pengelolaan Lahan Gambut Yang Berkelanjutan Dan Berwawasan Lingkungan. Jurnal Alami 2(1):12-16.

Musnawar, E. I. 2006. Pupuk Organik Cair dan Padat: Pembuatan dan Aplikasi. Penebar Swadaya.Jakarta

Nasution, A. 2009. Aplikasi Limbah Cair Pabrik Kelapa Sawit Untuk Perbaikan Status Beberapa Hara Makro Ultisol dan Hasil Kedelai. Skripsi Fakultas Pertanian Universitas Jambi.

Naibaho, P.M., 1999, Aplikasi Biologi dalam Pembangunan Industri Berwawasan Lingkungan, Jurnal Visi 7.

Nursanti, I. dan Meilin, A. 2011.Respon bibit kelapa sawit terhadap pemberian limbah cair pengolahan kelapa sawit (LCPKS) sebagai pupuk organik di pembibitan awal. Jurnal Ilmiah Batang Hari Jambi, volume 11: 70-74.

Nyakpa, M. Y., A.M. Lubis., M.A. Pulung., A.G. Amrah., A. Munawar., G.B. Hong., dan N. Hakim. 1988. Kesuburan Tanah. Unila, Lampung

Pahan, I. 2008. Panduan Lengkap Kelapa Sawit: Manajemen Agribisnis dari Hulu hingga Hilir. Jakarta: Penebar Swadaya.

Pasaribu T, Sinurat A.P, Purwadaria, Supriyati, J. Rosida, dan Helmi Hamid. 2011. Peningkatan Nilai Gizi Lumpur Sawit Melalui Proses Fermentasi: Pengaruh Jenis Kapang, Suhu, dan Lama Proses Enzimatis. Balai Penelitian Ternak. Bogor. 
Rachman, E., L. Maria dan T. Yomi. 2008. Perbanyakan Tanaman Secara Vegetatif. Makalah Dasar-Dasar Agronomi. Program Studi Agribisnis. Universitas Jambi. Jambi.

Rosneti, H. 2009. Pengaruh Limbah Cair Pabrik Kelapa Sawit dan Bokashi Terhadap

Tanaman Jagung Sayur (Zea mays Linn). Tesis Magister Pertanian Program Pascasarjana Universitas Islam Riau, Pekanbaru.

Setyamidjaja, Dj. 2006. Seri Budidaya Kelapa Sawit, Teknik Budi Daya, Panen, Pengolahan. Yogyakarta.

Siregar, F. A. dan Liwang, T. 2001. Aplikasi Limbah cair. Jakarta.

Sholeh, K. 2016. Pemberian Limbah Cair Pabrik Kelapa Sawit (LCPKS) dan NPK Tablet Terhadap Pertumbuhan Bibit Kelapa Sawit (Elaeis guineensis Jacq) di Tanah Gambut Pada Pembibitan Utama. Fakultas Pertanian Universitas Riau. Riau.

Subagyo H.N., Suharta dan A.B. Siswanto. 2004. Tanah-Tanah Pertanian diIndonesia dalam Sumber Daya Lahan Indonesiadan Pengolahannya. Pusat Penelitian Tanah dan Agroklimat. Bogor.

Subandi. 2007. Teknologi Produksi dan Strategi Pengembangn Kedelai pada Lahan Kering Masam. Iptek Tanaman Pangan. Vol 2, No.1.

Sudaryono. 2009. Tingkat Kesuburan Tanah Ultisol Pada Lahan Pertambangan Batubara Sangatta, Kalimantan Timur. J. Tek. Ling 10 (3).

Sunarko. 2007. Budi Daya dan Pengolahan Kebun Kelapa Sawit dengan Sistem Kemitraan. Jakarta.

Sutarta E.S., Tobing P.L, Winarna dan Sufianto. 2003. Aplikasi Limbah Cair Pabrik Kelapa Sawit pada Perkebunan Kelapa Sawit. Makalah pada Pertemuan Teknis Kelapa Sawit pada Perkebunan Kelapa Sawit. Medan. 13-14 Juni 2003.

Tan, K. H. 2007. Principles of Soil Chemistry Fourth Edition. CRC Press Tailor and Francis Group. Boca Raton. London. New York. 362 hal.

Wahyuaskari. 2005. TanahUltisol. Diaskses tanggal 19.09.2016. Pukul 13.30. 